Muhammad Haramain

Nurhikmah

Abd. Wahidin

\title{
STRATEGI PROGRAM STUDI DALAM MENINGKATKAN STANDAR MUTU AKREDITASI
}

Studi Kasus Program Studi

Manajemen Dakwah IAIN Parepare

Tahun 2018

Editor

H. Islamul Haq

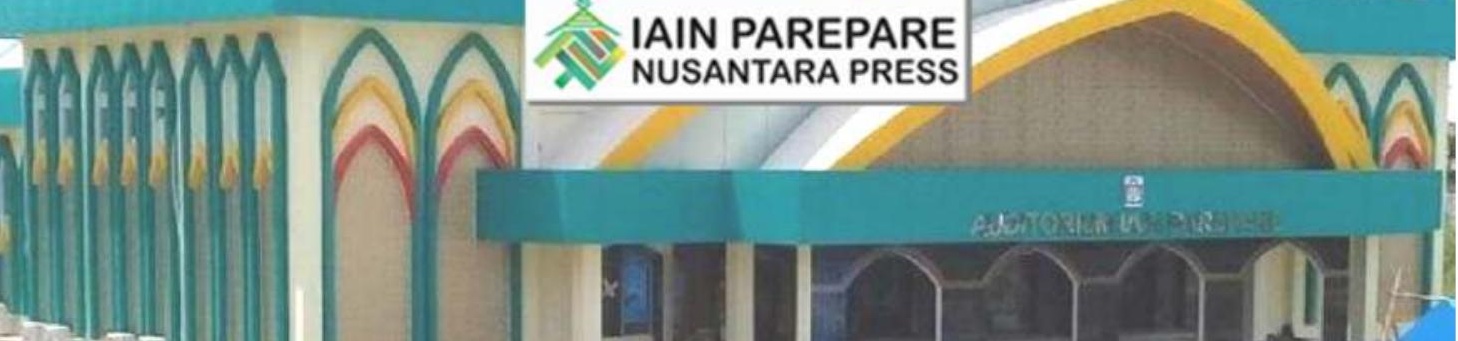


STRATEGI PROGRAM STUDI DALAM MENINGKATKAN STANDAR MUTU AKREDITASI: Studi Kasus Program Studi Manajemen Dakwah IAIN Parepare Tahun 2018

Penulis:

Muhammad Haramain

Nurhikmah

Abd. Wahidin

Editor:

H. Islamul Haq

Penyunting dan Penata Letak:

Tim Pusat Penerbitan dan Publikasi Ilmiah

LP2M IAIN Parepare

Penerbit:

IAIN Parepare Nusantara Press

\section{Redaksi:}

Jl. Amal Bakti No.8, Soreang

Parepare, Sulawesi Selatan

Indonesia 91131

ISBN: 978-623-90768-9-4

Cetakan Pertama, Juli 2019

118 halaman; $14,8 \times 21 \mathrm{~cm}$

\section{IAIN PAREPARE} NUSANTARA PRESS

Copyright $\odot$ IAIN Parepare Nusantara Press, 2019 


\section{Kata Pengantar}

\section{Bismillah wa bihamdih}

Puji syukur ke hadirat Allah SWT., atas perkenan dan hidayahNya, Tim Penulis dapat melaksanakan penelitian ini hingga mewujudkannya dalam bentuk laporan hasil penelitian. Shalawat serta salam kepada Nabi Muhammad saw, yang menjadi teladan bagi semesta alam.

Alhamdulillah, buku ini tiba pada publikasinya. Tim merasa sangat terbantu oleh partisipasi dan bantuan dari berbagai pihak. Dari lubuk hati terdalam, Tim memberikan apresiasi dan terimakasih sebesar-besarnya kepada:

1. Bapak Rektor IAIN Parepare, Dr. Ahmad S. Rustan, M.Si., selaku pimpinan yang telah mermberikan peluang dan arahan terhadap peningkatan kualitas SDM Civitas Akademika IAIN Parepare melalui kebijakan-kebijakan strategis, khususnya bagi kesempatan yang diberikan kepada Tim dan penelitian ini;

2. Bapak Kepala dan Sekretaris P3M IAIN Parepare, Dr. Zainal Said, M.H. dan Dr. Sitti Jamilah Amin, M.Ag., serta seluruh staf dan pengurus P3M yang telah banyak 
memberikan petunjuk teknis dan bantuan moril-materiil, sehingga terselesaikannya penelitian ini;

3. Bapak Kepala P2M IAIN Parepare, Dr. Firman, M.Pd. beserta jajarannya yang berkontribusi menambah infromasi dan kajian berharga bagi penelitian ini.

4. Bapak Ketua Jurusan Dakwah dan Komunikasi, Dr. H. Muhammad Saleh, M.Ag., dan Ibu Pena Prodi Manajemen Dakwah Dr. Zulfah, M.Pd., atas segala petunjuk dan informasi yang memperkaya analisis dan kebutuhan konten penelitian ini;

5. Bapak dan Ibu Tim Reviewer Hasil Penelitian Dosen IAIN Parepare Tahun 2018, atas segala arahan, masukan dan rekomendasi yang sangat berguna bagi perbaikan penelitian ini;

6. Bapak Ibu Dosen yang ikut terlibat dalam penelitian ini sangat membantu kami, yang tidak bisa disebutkan satu per satu;

7. Last but not the least, seluruh pihak yang membantu Tim, baik moril-materiil maupun keluangan waktu dan tenaga dalam penyempurnaan penelitian, Jazaakumullah khairal jazaa'.

Akhirnya, kami mengharapkan kritik dan saran terhadap perbaikan dan peningkatan penelitian ini hingga waktu-waktu yang akan datang. Buku ini walaupun telah dianggap selesai, masih memiliki kekurangan, baik pada aspek temuan data maupun metodologi. 
Kami berharap buku ini dapat memberikan kontribusi bagi keilmuan dan peningkatan kelembagaan di masa-masa yang akan datang.

Parepare, 8 Juli 2019

Tim Penulis 


\section{Daftar Isi}

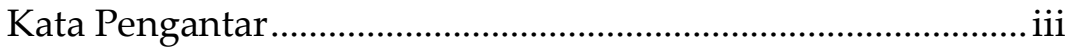

Daftar Isi........................................................................... vi

Bab I

Eksistensi dan Urgensi Program Studi dalam

Meningkatkan Mutu: Kelembagaan dan Luaran ................... 1

Bab II

Urgensi Mutu Akreditasi Program Studi 7

\section{Bab III}

Peningkatan Kualitas Mutu Akreditasi dengan Total Quality Management (TQM) ................................................................17

1. Manajemen Mutu Terpadu Pada Lembaga Pendidikan Tinggi 17

2. Manajemen Mutu Terpadu (TQM).................................. 19

3. Analisis Akar Permasalahan dengan Tool TQM (Fishbone)...................................................................... 21

C. Strategi Peningkatan Status Akreditasi Program Studi ... 22

\section{Bab IV}

Realitas Aktualisasi Mutu Program Studi: Studi Kasus Program Studi Manajemen Dakwah IAIN Parepare

1. Visi, Misi, Tujuan, dan Indikator Prodi Bermutu. 27 
2. Kebijakan Strategi Peningkatan Mutu Yang Diterapkan Di Prodi Manajemen Dakwah IAIN Parepare

3. Strategi Peningkatan Mutu Program Studi Bermutu di Prodi Manajemen Dakwah IAIN Parepare 47

4. Capacity Building Pendidik dan Tenaga Kependidikan Bermutu .................................................. 52

5. Kepemimpinan Mutu (Quality Leadership) ...................54

6. Perspektif Pengembangan Mutu Prodi Efektif 60

\section{Bab V}

\section{Ikhtiar Progresif dalam Mewujudkan Mutu Akreditasi} Program Studi.......................................................................... 75

1. Visi, Misi, Tujuan, dan Indikator Prodi Bermutu ............ 75

2. Kebijakan Strategi Peningkatan Mutu ............................ 77

3. Strategi Peningkatan Mutu Program Studi Bermutu di Prodi Manajemen Dakwah IAIN Parepare.....

4. Capacity Building Pendidik dan Tenaga Kependidikan

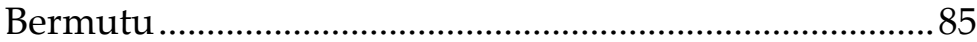

5. Kepemimpinan Mutu (Quality Leadership) ...................88

6. Perspektif Pengembangan Mutu Program Studi Efektif

Bab VI

Penutup. .98

\section{Daftar Pustaka}

